Wojciech Szafrański

w.szafr@amu.edu.pl

orcid.org/0000-0001-8420-4673

Uniwersytet im. Adama Mickiewicza w Poznaniu

Wydział Prawa i Administracji

Św. Marcin 90

61-714 Poznań

\title{
Nowe regulacje dotyczące przeciwdziałania praniu pieniędzy w obrocie dziełami sztuki. Między implementacją V AMLD a rozwiązaniem systemowym
}

New regulations to counteract money laundering in the trading of works of art. Between the implementation of AMLD V and the systemic solution

Summary: Implementing the 5th AML (Anti-Money Laundering) Directive in the form of a 2021 amendment to the Act on Counteracting Money Laundering and Terrorism Financing in Poland is of fundamental importance for the market. It will be binding upon entities such as entrepreneurs operating in the field of trading in works of art, collectors' items, and antiques covered by transactions worth at least 10,000 euros. The AML Directive presents a fragmentation of the Polish legal regulations on trade and thus the obligations imposed on intermediaries in the art market, depending on whether the regulations are developed based on cultural heritage protection regulations or economic and financial regulations. It shows the incompatibility of concepts used in both fields and the range of meanings of legal concepts that are directly relevant for the law's application, and the specification of obligations imposed on entrepreneurs specialized in the trade of what is broadly understood as cultural 


\section{ARTYKUEY}

Wojciech Szafrański

goods. The essential elements of AML, crucial for entities operating in the art market, were presented. Attention was also paid to further work on trading regulations based on the due diligence model.

Keywords: AMLD V, counteracting money laundering and terrorism financing, art market, works of art, auction houses, galleries

Streszczenie: Implementacja V dyrektywy AML (Anti-Money Laundering) w postaci nowelizacji ustawy o przeciwdziałaniu praniu pieniędzy i finansowaniu terroryzmu w 2021 r. ma zasadnicze znaczenie dla rynku. Podmiotami obowiązanymi stali się przedsiębiorcy prowadzący działalność polegającą obrocie lub pośrednictwie w obrocie dziełami sztuki, przedmiotami kolekcjonerskimi oraz antykami w zakresie transakcji o wartości co najmniej 10 tys. euro. Na kanwie regulacji AML przedstawione zostało „rozwarstwienie” polskich regulacji prawnych odnoszących się do obrotu, a tym samym obowiązków nałożonych na pośredników na rynku sztuki w zależności od tego, czy przepisy stanowią pochodną regulacji dotyczących ochrony dziedzictwa, czy regulacji gospodarczo-finansowych. Ukazana została niekompatybilność siatki pojęciowej i zakresów znaczeniowych pojęć prawnych mających bezpośrednie znaczenie dla stosowania prawa i konkretyzacji obowiązków nałożonych na przedsiębiorców wyspecjalizowanych w obrocie, którego przedmiotem są szeroko rozumiane dobra kultury. Przedstawiono najważniejsze elementy AML istotne dla podmiotów na rynku sztuki. Podkreślono konieczność dalszych prac nad regulacjami w zakresie obrotu opartymi na konstrukcji należytej staranności (due diligence).

Słowa kluczowe: V AMLD, przeciwdziałanie praniu pieniędzy i finansowaniu terroryzmu, rynek sztuki, dzieła sztuki, domy aukcyjne, galerie

\section{Narastające regulacje prawne odnoszące się do rynku sztuki}

Zainteresowanie polskiego ustawodawcy zagadnieniami z obszaru obrotu dziełami sztuki czy szeroko pojmowanym rynkiem sztuki z perspektywy ostatnich 30 lat trudno uznać za kompleksowe. Było ono raczej wybiórcze i dotyczyło systemu ochrony dziedzictwa, a przede wszystkim: spraw wywozowych, ograniczeń prawa własności w odniesieniu do zabytków (w szczególności wpisanych do rejestru) i ich konsekwencji dla obrotu, prawa pierwszeństwa i prawa pierwokupu muzeów rejestrowanych, a także podrabiania zabytków i zbywania podrobionych 
zabytków ${ }^{1}$. Przypadki zainteresowania ustawodawcy rynkiem sztuki w latach 1988-2021 bez "katalizatora dziedzictwa”, z wyjątkiem pierwszej ustawy o działalności gospodarczej z 1988 r. $^{2}$ (bezskutecznie wprowadzającej koncesjonowanie obrotu dobrami kultury powstałymi przed 9 maja $\left.1945 \mathrm{r} .{ }^{3}\right)$, były incydentalne ${ }^{4}$. $Z$ reguły wiązały się one ze zmianami w innych aktach prawnych (dot. m.in. droit de suite w prawie autorskim, przepisów o aukcjach w Kodeksie cywilnym) i choć wpływały na rynek sztuki, to nie były przedmiotem refleksji w odniesieniu do obrotu dobrami kultury ani tym bardziej wyodrębnionej regulacji prawnej dotyczącej bezpośrednio i kompleksowo rynku sztuki.

Paradoksalnie istnieje rodzaj nieufności między rynkiem sztuki a ochroną dziedzictwa, nieufności budowanej najczęściej zarówno przez pośredników na rynku sztuki, jak i podmiotów odpowiedzialnych za ochronę dziedzictwa kulturowego. $Z$ jednej bowiem strony brak jest wyobrażenia o pozytywnej roli rynku w systemie ochrony dziedzictwa; dla części decydentów politycznych mających na uwadze znaczne straty w materialnej kulturze polskiej będące efektem wojny oraz konieczność ochrony wszystkiego rynek jawi się przede wszystkim jako zagrożenie dla dziedzictwa i czynnik odpowiedzialny za zwiększającą się kapitalizację (co uznawane jest często za niekorzystny element). $Z$ drugiej strony sami uczestnicy rynku, a właściwie - przy naturalnej asymetrii informacji - najbardziej zorientowani na tym rynku, czyli pośrednicy, nie wypracowali w ciągu tych lat realnych (a nie tylko papierowych) rozwiązań na poziomie samoorganizacji rynku, które by eliminowały funkcjonujące na nim patologie i tworzyły powszechne zasady należytej staranności z uwagi na jego specyfikę, czyli przedmiot obrotu. Obecnie uczestnicy rynku sztuki bardziej liczą na brak zmian w systemie ochrony dziedzictwa wpływających na rynek sztuki, spodziewając się przede wszystkim dalszych ograniczeń i nakładanych obowiązków, a nie ustawodawczej pomocy rynkowi. Dla uczestników rynku stało się to jeszcze bardziej zauważalne - jako wręcz potwierdzenie własnego spojrzenia w momencie wprowadzenia w 2017 r. do ustawy z dnia 23 lipca 2003 r. o ochronie zabytków i opiece nad zabytkami ${ }^{5}$ (dalej: ustawa o ochronie zabytków) regulacji dotyczących ksiąg ewidencyjnych przy okazji uchwalenia ustawy z dnia

1 O wzajemnych relacjach z perspektywy prawnej ochrony dziedzictwa i rynku sztuki zob. szerzej:W. Szafrański, Ochrona dziedzictwa kulturalnego a rynek sztuki. Zagrożenia, korzyści, perspektywy, w: W. Pływaczewski, B. Gadecki (red.), Ochrona dziedzictwa kulturowego i naturalnego. Perspektywy prawna i kryminologiczna, C.H. Beck, Warszawa 2015, s. 125-140.

2 Ustawa z dnia 23 grudnia 1988 r. o działalności gospodarczej, Dz. U. Nr 41, poz. 324.

3 Bezskuteczność wynikała z niewprowadzenia przepisów wykonawczych w tym zakresie do tej ustawy, wskutek czego obrót takimi obiektami nie był koncesjonowany.

4 Jednocześnie na przełomie lat 80. i 90. XX w. nastąpił rozpad instytucji państwowego systemu sztuki zajmujących się handlem. O sytuacji przekształceń i początku rynku sztuki w tym okresie zob. J. Banasiak, Proteuszowe czasy. Rozpad państwowego systemu sztuki 1982-1993, Muzeum Sztuki Nowoczesnej i Akademia Sztuk Pięknych w Warszawie, Warszawa 2020, s. 341-374 i s. 480-504.

5 Ustawa z dnia 23 lipca 2003 r. o ochronie zabytków i opiece nad zabytkami, Dz. U. Nr 162, poz. 1568 ze zm. 


\section{ARTYKUŁY}

Wojciech Szafrański

25 maja 2017 r. o restytucji narodowych dóbr kultury ${ }^{6}$, a w konsekwencji rozporządzenia Ministra Kultury i Dziedzictwa Narodowego z dnia 4 grudnia 2017 r. w sprawie ksiąg ewidencyjnych prowadzonych przez podmioty gospodarcze wyspecjalizowane z zakresie obrotu zabytkami na terytorium Rzeczypospolitej Polskiej?. Regulacje te poświęcone zostały bezpośrednio, jak określa ustawa o ochronie zabytków, podmiotom gospodarczym wyspecjalizowanym w obrocie zabytka$\mathrm{mi}^{8} \mathrm{i}$ wzbudziły wiele kontrowersji uczestników rynku, przede wszystkim z racji formy (księgi papierowej') czy obowiązku wydawania przez podmiot prowadzący księgę ewidencyjną odpisu lub kopii wpisu na żądanie zbywcy lub nabywcy zabytku objętego wpisem. Najistotniejsza okazała się sprawa definicji zabytku. Nie jest tajemnicą, że rynek sztuki żyje nie tylko ze sztuki dawnej, ale i współczesnej, do której pośrednicy na rynku sztuki zaliczają dzieła powstałe po 1945 r. i taką datę chcieliby uznawać za "granicę" zabytku (taką instrukcję wydało też Stowarzyszenie Antykwariuszy i Marszandów Polskich), co jest absolutnie contra legem. Drugi element niepokojów na linii "rynek sztuki - ochrona dziedzictwa” dotyczy spraw wywozowych - zarówno samych kategorii wywozowych (głównie kategorii wartości), procedury (zdaniem uczestników rynku jej przewlekłości), jak i zakazów wywozu (bez korelacji z zakupem takich zabytków nawet fakultatywnym - procedury takiej obecnie brak w polskim systemie prawnym).

Dotychczas sprawy obrotu dobrami kultury rozgrywały się przede wszystkim między rynkiem sztuki (przedsiębiorcami wyspecjalizowanymi w obrocie) a organami predestynowanymi do ochrony dziedzictwa, czyli głównie Ministrem Kultury, Dziedzictwa Narodowego i Sportu (lub Generalnym Konserwatorem Zabytków) oraz wojewódzkim konserwatorem zabytków (choćby w sprawach czasowych wywozów, rejestracji ksiąg ewidencyjnych). Jednocześnie z uwagi na fakt, że różne departamenty w Ministerstwie KDNiS zajmują się kwestią obrotu bardziej czy mniej świadomie (nie ma podmiotu, który koordynuje sprawy obrotu jako całości ${ }^{10}$ ), po-

6 Ustawa z dnia 25 maja 2017 r. o restytucji narodowych dóbr kultury, Dz. U. poz. 1086.

7 Rozporządzenie Ministra Kultury i Dziedzictwa Narodowego z dnia 4 grudnia 2017 r. w sprawie ksiąg ewidencyjnych prowadzonych przez podmioty gospodarcze wyspecjalizowane z zakresie obrotu zabytkami na terytorium Rzeczypospolitej Polskiej, Dz. U. poz. 2249.

8 W kontekście ustawy z dnia 6 marca 2018 r. Prawo przedsiębiorców (Dz. U. poz. 646) powinna nastąpić zmiana w ustawie o ochronie zabytków, w rzeczy wistości bowiem obowiązek informacyjny w postaci ksiąg ewidencyjnych dotyczy przedsiębiorców, a nie bliżej nieokreślonych podmiotów gospodarczym (określenie z wcześniejszych ustaw o obrocie gospodarczym).

9 W rzeczywistości było to w zamierzeniu ustawodawcy podyktowane zapewne nieponoszeniem kosztów przez państwo, które w przypadku wprowadzenia systemu teleinformatycznego musiałoby wydatkować na ten cel środki finansowe, a tym samym przerzuceniem kosztów na przedsiębiorców i możliwością działania od razu systemu ksiąg ewidencyjnych. Czas na stworzenie systemu teleinformatycznego bowiem byłby z pewnością bardzo długi i przez to regulacje pozostawałyby jedynie na papierze. Świadczyć o tym mogą dotychczasowe doświadczenia z krajowym rejestrem utraconych dóbr kultury, który w zakresie regulacji prawnych obowiązuje, ale brak systemu informatycznego, a więc tym samym rejestr nie działa. 
średnicy na rynku sztuki postrzegali właśnie to ministerstwo jako podstawową instytucję odpowiedzialną za potencjalne przyszłe zmiany, które mogą być najistotniejsze dla rynku. Takie przeświadczenia przez długi czas panowało tylko na rynku wtórnym - głównie wśród podmiotów aukcyjnych, które na bieżąco napotykały ograniczenia wynikające z ochrony dziedzictwa, podczas gdy rynek pierwotny galerie sztuki współczesnej ze względu na przedmiot obrotu raczej nie interesowaty się regulacjami z obszaru ochrony dziedzictwa ${ }^{11}$.

Z racji w ogóle funkcjonowania w sferze gospodarczej przedsiębiorcy na rynku sztuki, podobnie jak zbywcy i nabywcy (osoby fizyczne i prawne), podlegali szeroko pojętym regulacjom prawa finansowego czy gospodarczego. Nie dotyczyły one tylko rynku sztuki, lecz w ogóle obrotu dziełami sztuki, inaczej niż regulacje związane z podatkiem od towarów i usług. W ustawie z dnia 11 marca 2004 r. o podatku od towarów i usług ${ }^{12}$ (dalej: ustawa o VAT), w pierwotnej uchwalonej wersji znajdował się rozdział 4 dotyczący szczególnych procedur w zakresie dostawy towarów używanych, dzieł sztuki, przedmiotów kolekcjonerskich i antyków (art. 120). Tym samym do polskiego systemu prawnego wprowadzono definicje legalne: „dzieło sztuki”, „przedmiot kolekcjonerski” i „antyk” wraz z regulacjami dotyczącymi już bezpośrednio obrotu takimi dobrami, czyli m.in. kwestię stawek podatkowych, systemu VAT marża. Kluczowe z punktu widzenia niniejszego artykułu jest jednak samo przyjęcie siatki pojęciowej, a w tym przypadku była ona konsekwencją przyjęcia rozwiązań z prawa celnego UE, zgodnie z działem 97 WTC (Wspólnej Taryfy Celnej), zatytułowanym „Dzieła sztuki, przedmioty kolekcjonerskie i antyki"13. Jej przeniesienie do polskiego porządku - ustawy o VAT w ramach art. 120 spowodowało, że obowiązująca i istotna dla uczestników obrotu stała się siatka pojęciowa właśnie z ustawy o VAT, która nieznacznie tylko zmodyfikowana względem swojej pierwotnej wersji z 2004 r. obowiązuje

regulacji nie pozostaje już w kontakcie z rynkiem sztuki. Departament ten zajmuje się też sprawami restytucyjnymi i prowadzi w imieniu ministra krajowy wykaz zabytków skradzionych lub wywiezionych za granicę niezgodnie z prawem. Departament Narodowych Instytucji Kultury prowadził programy „Narodowe kolekcje sztuki współczesnej” $\mathrm{i}$ „Regionalne kolekcje sztuki współczesnej”, istotne z punktu widzenia funkcjonowania tzw. pierwotnego rynku sztuki. Departament Ochrony Zabytków zajmuje się m.in. sprawami wywozowymi. Departament Dziedzictwa Kulturowego, który ma w swoim obszarze działania sprawy muzeów, dziś nie dostrzega w sposób znaczący spraw powiązanych z rynkiem sztuki, czyli choćby depozytów. Odnośnie do działań na rynku sztuki organów państwa zob. szerzej: W. Szafrański, Rynek sztuki w Polsce z perspektywy administracji publicznej, w: M. Jankowska, P. Gwoździewicz-Matan, P. Stec (red.), Własność intelektualna a dziedzictwo kulturowe. Księga jubileuszowa dedykowana Profesorowi Wojciechowi Kowalskiemu, lus Publicum, Warszawa 2020, s. 647-668.

11 Wyjątkiem były galerie, również objęte obowiązkiem prowadzenia ksiąg ewidencyjnych, gdy zajmowały się obrotem rzeczami ruchomymi, które w świetle ustawy o ochronie zabytków stanowią zabytki.

12 Ustawa z dnia 11 marca 2004 r. o podatku od towarów i usług, Dz. U. Nr 54, poz. 535.

13 Początki sięgają rozporządzenia Rady (EWG) nr 2658/87 w sprawie nomenklatury taryfowej i statystycznej oraz w sprawie wspólnej taryfy celnej (Dz. U. WE L 256 z 7.09.1987) i załącznika 1 do tego rozporządzenia, później zmodyfikowanego przez rozporządzenie Rady (WE) nr 254/200 (Dz. U. WE L 28 z 3.02.2001) i akty prawne wprowadzające scaloną nomenklaturę celną (CN). 


\section{ARTYKUŁY}

Wojciech Szafrański

do dnia dzisiejszego ${ }^{14}$. I choć ustawodawca wyraźnie wskazuje jej użyteczność na potrzeby przede wszystkim konkretnego rozdziału ustawy o VAT, to jednak nie jest tajemnicą, że w toku projektowania jakichkolwiek nowych przepisów z obszaru zbliżonego projektodawcy starają się wprowadzać te same pojęcia, jakie już wcześniej „sprawdziły się w działaniu”. A gdy dodatkowo pochodzą one z ustawodawstwa europejskiego, które też dba o kompatybilność pojęciową, to nie dziwi fakt, że w zakresie szeroko pojętych regulacji finansowych to odwołanie pojęciowe jest oczywiste (a więc siatka pojęciowa z dawnego działu 97 WTC przenika także do dyrektywy AML, w tym w szczególności dyrektywy Parlamentu Europejskiego i Rady (UE) 2018/843 z dnia 30 maja 2018 r. zmieniającej dyrektywę (UE) 2015/849 w sprawie zapobiegania wykorzystywaniu systemu finansowego do prania pieniędzy lub finansowania terroryzmu oraz zmieniająca dyrektywy 2009/138/WE i 2013/36/UE ${ }^{15}$ (dalej: V AMLD).

Co istotne, mniej więcej $w$ tym samym czasie, $w$ którym procedowano nową ustawę o VAT z 2004 r., zakończono prace nad nową ustawą o ochronie zabytków i opiece nad zabytkami, która weszła w życie już w 2003 r. W jej pierwotnej wersji brak było istotnych regulacji dotyczących obrotu. Z punktu widzenia systemu ochrony dziedzictwa zmieniała ona jednak zasadniczo siatkę pojęciową, centralne miejsce ustawodawca przyznał bowiem pojęciu „zabytek”, spychając tym samym pojęcie "dobro kultury” na dalsze miejsce. Brak kompatybilności siatki pojęciowej w różnych aktach prawnych odnoszących się do obrotu oraz ochrony dziedzictwa i coraz trudniejsze wyznaczanie zakresów pojęć powodują i powodować będą nadal w praktyce to, że podmioty objęte obowiązkami ustawowymi są zmuszane do działań dwutorowych, nieraz pokrywających się, a nieraz odległych od siebie.

$Z$ jednej bowiem strony ograniczenia w obrocie z racji ochrony dziedzictwa pojawiały się w ustawie o ochronie zabytków czy ustawie $z$ dnia 25 maja 2017 r. o restytucji narodowych dóbr kultury, gdzie centralnymi pojęciami - z definicjami legalnymi są: „zabytek”, „dobro kultury”, „, narodowe dobro kultury RP”, „zagraniczne narodowe dobro kultury", natomiast drugorzędnymi pojęciami są „dzieła sztuki” i „kolekcje” (bez definicji legalnej), a inne pojęcia, używane w ustawie o VAT, tj. „przedmioty kolekcjonerskie” czy „antyki”, w ogóle nie pojawiają się w regulacjach w obszarze ochrony dziedzictwa. $Z$ drugiej jednak strony należy dostrzec daleko idącą erozję pojęcia zabytku z powodu konieczności wprowadzania do polskiego systemu prawnego rozwiązań z ratyfikowanych przez Polskę umów międzynarodowych, prawa unijnego (w tym także w trybie implementacji), w których cen-

14 O definicjach dzieł sztuki, przedmiotów kolekcjonerskich i antyków z punktu widzenia celów taryfowych i działu 97 CN zob. szerzej: W. Paczuski, Handel dziełami sztuki w Unii Europejskiej, Wolters Kluwer, Kraków 2005, s. 31-65.

15 Dyrektywa Parlamentu Europejskiego i Rady (UE) 2018/843 z dnia 30 maja 2018 r. zmieniająca dyrektywę (UE) 2015/849 w sprawie zapobiegania wykorzystywaniu systemu finansowego do prania pieniędzy lub finansowania terroryzmu oraz zmieniająca dyrektywy 2009/138/WE i 2013/36/UE, Dz. Urz. UE L 156 z 19.06.2018 r. 
tralnym pojęciem jest pojęcie „dobro kultury”, a nie „zabytek” (czyli pojęcie węższe pod względem zakresu od pojęcia "dobro kultury").

Kto do kogo powinien się dostosować, by zaistniała kompatybilność na poziomie przede wszystkim siatki pojęciowej? Twórcy regulacji z obszaru obrotu (na poziomie projektodawczym najczęściej Ministerstwo Finansów) dotychczas nie byli zbytnio zainteresowani złożonością legislacyjną systemu ochrony dziedzictwa (czyli wielu ustaw z "ustawą matką" na czele, tj. ustawą o ochronie zabytków).

Obrót dobrami kultury stał się obszarem, w którym w zakresie projektodawczym (a w konsekwencji ustawowym) zainteresowanie przejawia zarówno Ministerstwo Kultury, Dziedzictwa Narodowego i Sportu, jak i Ministerstwo Finansów. Trudno jednak uznać owo zainteresowanie za wspólne w rozumieniu współdziałania przy tworzeniu projektów aktów prawnych. Dla Ministerstwa Finansów kluczowa jest kompatybilność definicyjna (siatka pojęciowa) z regulacjami unijnymi. Dla Ministerstwa Kultury, Dziedzictwa Narodowego i Sportu z kolei najistotniejsza jest spójność systemu i nadrzędność celu, czyli ochrona dziedzictwa (stąd wyodrębnione pojęciowe kategorie rzeczy ruchomych - zabytków itd.). Tym samym wprowadzanie do systemu kolejnych kategorii, np. przeniesionych z ustawy o VAT, oraz definicji legalnych docelowo rozbije ten system. Paradoksalnie, im bardziej obrót będzie przedmiotem zainteresowania obu organów, tym częściej będzie dochodziło do krzyżowania się obowiązków podmiotów związanych z szeroko pojętym obrotem dobrami kultury, dopóki nie nastąpi spójność pojęć i ich zakresów znaczeniowych. Dla pośredników na rynku sztuki, i w ogóle dla uczestników obrotu w tym zakresie, stanie się to coraz bardziej uciążliwe wraz z przyrastaniem regulacji prawnych pochodzących zarówno z obszaru ochrony dziedzictwa, jak i z obszaru obrotu gospodarczego i prawa finansowego jako takiego. Wciąż zwiększa się liczba takich regulacji. W ostatnim czasie jako przykład regulacji poświęconych rynkowi sztuki - pośrednikom w obrocie - można uznać implementację $\mathrm{V}$ AMLD do polskiego porządku prawnego $\mathrm{w}$ postaci ustawy z dnia 30 marca 2021 r. o zmianie ustawy o przeciwdziałaniu praniu pieniędzy oraz finansowaniu terroryzmu oraz niektórych innych ustaw ${ }^{16}$.

\section{Implementacja V AMLD w postaci nowelizacji ustawy o przeciwdziałaniu praniu pieniędzy oraz finansowaniu terroryzmu - znaczenie dla podmiotów na rynku sztuki w Polsce}

Tworzenie polskiego systemu przeciwdziałania praniu pieniędzy miało miejsce w Polsce w pierwszej połowie lat 90. XX w. Jednakże przez długi czas, jak wskazywał Wiesław Pływaczewski, „problematyka prania pieniędzy za pośrednictwem

16 Ustawa z dnia 30 marca 2021 r. o zmianie ustawy o przeciwdziałaniu praniu pieniędzy oraz finansowaniu terroryzmu oraz niektórych innych ustaw, Dz. U. poz. 815. 


\section{ARTYKUŁY}

Wojciech Szafrański

mechanizmów kojarzonych z rynkiem dzieł sztuki pozostawała poza głównym nurtem zainteresowań organów ścigania"17. Wynikało to w głównej mierze z braku specjalistycznego przygotowania (kapitałochłonność działań, wyodrębnienie specjalistycznych jednostek i ich wyszkolenie, konieczność korzystania z kosztownego nieraz zaplecza eksperckiego). W państwach, w których zdecydowano się na intensyfikację działań organów w obszarze obrotu dziełami sztuki, wzrosła efektywności policji i innych służb, nie tylko w zakresie ścigania przestępstw przeciw dziedzictwu kulturowemu, ale i kwestii wiarygodności transakcji na rynku sztuki, a tym samym oszustw podatkowych czy, szerzej, prania pieniędzy ${ }^{18}$. Tym samym wzrost patologii na rynku sztuki prowadzi do występowania przestępczości na tym rynku ${ }^{19}$, szczególnie w sytuacji, gdy dostrzegalne stają się: nieefektywność państwa w zakresie nadzoru w obrocie dobrami kultury, niedostatek regulacji prawnych, ale i niedostateczna wiedza organów państwa o rynku sztuki.

V AMLD była nie tyle zaskoczeniem dla rynku sztuki UE, ile niepewnością co do samych szczegółowych rozwiązań w różnych państwach, a zwłaszcza rzeczywistych działań organów publicznych w ramach przeciwdziałania praniu pieniędzy za pośrednictwem rynku sztuki. Warto jednocześnie wskazać, że choć Wielka Brytania opuściła Unię Europejską, to również przyjęła rozwiązania z V AMLD, wprowadzając początkowo sporo zamieszania na swoim rynku sztuki, jednym z najistotniejszych obok rynku amerykańskiego i chińskiego na świecie. Co jednak istotne, wiele z podmiotów objętych nowymi obowiązkami wynikających z V AMLD wciąż ich nie przestrzega bez względu na konsekwencje ${ }^{20}$. „Wymuszenia” ze strony pośredników brytyjskiego rynku sztuki na organach państwa w zakresie samej rejestracji w HMRC (HM Revenue\& Customs - organ nadzorczy ds. przepisów dotyczących prania pieniędzy w Wielkiej Brytanii) doprowadziły do zmiany terminu wejścia w życie nowych przepisów tej rejestracji - ze stycznia 2021 na 10 czerwca 2021 r. Niemniej wszelkie opóźnienia i tak nie zmienią samego trendu regulacji na rynkach sztuki w poszczególnych państwach. Zmiany w tym zakresie w obszarze rynku sztuki zaczynają mieć charakter międzynarodowy, także USA zamierzają w sposób pełniejszy niż dziś regulować swój rynek sztuki z perspektywy przeciwdziałania praniu pieniędzy.

17 W. Pływaczewski, Pranie pieniędzy oraz inne nielegalne transakcje finansowe z perspektywy międzynarodowego rynku dzieł sztuki, w: E.W. Pływaczewski (red.), Proceder prania pieniędzy i jego implikacje, Wolters Kluwer Polska, Warszawa 2013, s. 177.

18 Ibidem.

19 Zob. W. Pływaczewski, Patologie w obrębie współczesnego rynku dzieł sztuki - perspektywa krajowa i międzynarodowa, w: T. Gardocka, J. Sobczak (red.), Prawna ochrona zabytków, Wydawnictwo Adam Marszałek, Toruń 2014, s. 231-249; W. Szafrański, Mity i patologie obrotu dziełami sztuki, „Santander Art and Culture Law Review" 2015, nr 1(1), s. 135-172.

20 R. Neville, The art market is 'high risk' for money laundering, so ignore new regulations at your peril, „The Art Newspaper", 26.03.2021, https://www.theartnewspaper.com/comment/art-dealer-vs-solicitor-money-laundering-law-alters-the-relationship [dostęp: 20.06.2021]. 
Unia Europejska zdecydowała się w V AMLD na poszerzenie zakresu podmiotowego regulacji o:

- osoby prowadzące handel dziełami sztuki lub występujące w charakterze pośredników w handlu dziełami sztuki, w tym gdy handel taki prowadzony jest przez galerie sztuki i domy aukcyjne, jeżeli wartość transakcji lub szeregu powiązanych transakcji wynosi co najmniej 10 tys. euro,

- osoby przechowujące dzieła sztuki, prowadzące handel dziełami sztuki lub występujące w charakterze pośredników w handlu dziełami sztuki, gdy działalność taka prowadzona jest przez wolne porty, jeżeli wartość transakcji lub szeregu powiązanych transakcji wynosi co najmniej 10 tys. euro.

Tym samym Unia Europejska wyraziła konieczność objęcia obrotu dziełami sztuki większym nadzorem z perspektywy przeciwdziałania praniu pieniędzy. Oznaczało to, że przyczyną wprowadzonych zmian są doświadczenia różnych państw unijnych, ale też szerzej - z rynku międzynarodowego, dotyczące wykorzystywania obrotu dziełami sztuki do takich celów. Unia Europejska stanęła na stanowisku, aby regulacje w tym przedmiocie, bez względu na rzeczywisty stopień zagrożenia prania pieniędzy przez rynek sztuki w poszczególnych państwach, miały charakter powszechny. Nie ulega wątpliwości, że różne krajowe rynki sztuki mają odmienny stopień podatności na pranie za ich pomocą pieniędzy (a w niektórych państwach bezpośrednio na finansowanie terroryzmu) i nie zależy to, wbrew obiegowej opinii, przede wszystkim od wielkości rynku sztuki (tj. poziomu jego obrotów). Im większy rynek, tym większe ryzyko, ale i realność prania pieniędzy za pomocą rynku sztuki - to jeden z mitów często powtarzanych przez pośredników na rynku sztuki w państwach UE. Kluczem nie jest bowiem sama wielkość rynku, ale stopień nadzoru nad nim ze strony państwa, jego znajomości itp. Pośrednicy często nie zdają sobie sprawy z tego, że możliwe są sytuacje, w których pranie pieniędzy przez rynek sztuki następuje nawet bez ich wiedzy i możliwości dostrzeżenia tego. To właśnie regulacje w zakresie V AMLD mają wprowadzać rozwiązania, w których tzw. projekcja ryzyka przeniesiona jest przede wszystkich na profesjonalistów na tym rynku, czyli pośredników. Tym samym zasadne jest oparcie się na „przymuszeniu” regulacyjnym takich podmiotów do przeprowadzenia ocen ryzyka klientów, stworzenia własnych procedur w zakresie przeciwdziałania praniu pieniędzy i przeszkolenie odpowiednie personelu, odpowiedniej analizy due diligence klienta i systemu „czerwonych flag”, które wzbudzają podejrzenie prania pieniędzy i są podstawą do zawiadomienia o tym odpowiednich organów.

Znowelizowanie ustawy o przeciwdziałaniu praniu pieniędzy oraz finansowaniu terroryzmu w 2021 r. i objęcie nowej kategorii podmiotów z obszaru rynku sztuki obowiązkami w zakresie przeciwdziałania praniu pieniędzy nie były odpowiedzią na szerokie zjawisko prania pieniędzy w Polsce poprzez rynek sztuki, ale stanowiły konieczny element implementacji $\vee$ AMLD. Brak jest zresztą rzeczywistej wiedzy o skali tego zjawiska w Polsce. Wynika to z braku szerszej wiedzy organów państwa o rynku sztuki i mechanizmach na nim występujących. Próbą odczytania "stanu wiedzy” or- 


\section{ARTYKUŁY}

Wojciech Szafrański

ganów państwa o rynku sztuki jest Krajowa ocena ryzyka prania pieniędzy oraz finansowania terroryzmu ${ }^{21}$, w której niecałe trzy strony poświęcono rynkowi sztuki ${ }^{22}$. Można uznać, że zespół przygotowujący tę ocenę celowo nie przedstawił istotnych danych, kazusów przypadków czy mechanizmów występujących na polskim rynku sztuki z racji publicznego charakteru niniejszego raportu. Niemniej taka hipoteza w zasadzie upada wraz z lekturą dokumentu. Dane rynkowe przedstawione w Krajowej ocenie pochodzą przede wszystkim z raportów Artinfo.pl (raportu prywatnego, który ma charakter przede wszystkim inwestycyjny, tj. pisany jest z perspektywy potencjalnych inwestorów na tym rynku i w dużym stopniu bazuje na danych zebranych od domów aukcyjnych bez rzeczywistej weryfikacji transakcji - zarówno ich wysokości, jak i tego, czy w ogóle doszły one do skutku) oraz w mniejszym stopniu z danych GUS (który dopiero rozwija swoje ankiety w odniesieniu do rynku sztuki). Tym samym Krajowa ocena nie odpowiada ściśle na pytania nawet o liczbę podmiotów - przedsiębiorców na tym rynku - wyspecjalizowanych w obrocie. Całkowity brak wiedzy organów państwa w zakresie rynku pierwotnego - galeryjnego (niewykazanego w raporcie) i posługiwanie się opiniami „z kręgu marketingowego” ${ }^{23}$ dyskwalifikują wiarygodność tego raportu w odniesieniu do rynku sztuki. Na wskazanej wyżej bazie autorzy raportu dochodzą do wniosków dotyczących segmentu rynku sztuki, które można by nazwać uśrednionymi. Określając poziom podatności, zagrożenia i prawdopodobieństwa dla poszczególnych scenariuszy ryzyka prania pieniędzy, uznano inwestowanie środków pochodzących z nielegalnych źródeł w zakup antyków i dzieł sztuki na następujących „pułapach”: poziom podatności 3, poziom zagrożenia 2, poziom prawdopodobieństwa 2,624. W Krajowej ocenie sformułowano także podsumowującą opinię:

Wykorzystanie mechanizmu inwestowania środków pochodzących z nielegalnych źródeł w zakup antyków i dzieł sztuki jest postrzegane raczej jako mało atrakcyjny sposób prania pieniędzy. GIIF otrzymywał nieliczne informacje o wykorzystywaniu tej metody do prania pieniędzy. WNIOSEK: Wykorzystanie mechanizmu inwestowania środków pochodzących z nielegalnych źródeł w zakup antyków i dzieł sztuki stwarza średnie zagrożenie praniem pieniędzy ${ }^{25}$.

Kluczem do odczytywania Krajowej oceny jest słowo „średnie”, z jednej bowiem strony autorzy oceny nie lekceważą takiej możliwości prania pieniędzy poprzez rynek, z drugiej zaś mają swoiste alibi, gdyby wybuchła podobna afera jak w sprawie

\footnotetext{
21 Krajowa ocena ryzyka prania pieniędzy oraz finansowania terroryzmu, Ministerstwo Finansów, Warszawa 2019, https://www.gov.pl/attachment/717264b0-2867-4e41-98da-2e64cf158ac8 [dostęp: 20.06.2021]. 22 Ibidem, s. 48-50.

23 „Rynek sztuki jest największym segmentem rynku inwestycji alternatywnych, którego przedmiotem są obrazy, rzeźby, grafiki, plakaty, porcelana, antyki czy sztuka użytkowa, a popyt na dzieła jest uzależniony od okresu i miejsca ich powstania. Zaletą rynku sztuki jest niska wrażliwość na działanie cykli koniunkturalnych. Niepoddający się presji rynku indeks dzieł sztuki wyraźnie zwyżkował w okresach dekoniunktury gospodarczej" (Krajowa ocena..., s. 50).

24 Ibidem, s. 292.

25 Aneks $\mathrm{nr} 2$ „Scenariusze ryzyka prania pieniędzy”, s. 30, https://www.gov.pl/attachment/6d2509ff-5ff3-4928-b81d-3f096253721d [dostęp: 20.06.2021].
} 
Timeless Gallery i Gallery New Form, w których przypadku ciągle jeszcze toczą się postępowania. Wtedy łatwo przechodzi się od słowa „średnie” do „wysokie”. Na marginesie warto wskazać, że prawie nie były prowadzone w ostatnim czasie poważne kontrole celno-skarbowe czy kontrole podatkowe względem znaczących przedsiębiorstw na polskim rynku sztuki. Paradoksalnie więcej przeprowadzono kontroli ksiąg ewidencyjnych (czyli pewnego wycinka w zakresie obrotu zabytkami o wartości powyżej 10 tys. zł), a więc wynikających z ustawy o ochronie zabytków, czyli będących pochodną regulacji z zakresu systemu ochrony dziedzictwa, niż działań z obszaru skarbowo-podatkowego.

Pewnym usprawiedliwieniem może być to, że przedsiębiorcy prowadzący dziatalność w zakresie obrotu dziełami sztuki stali się instytucjami obowiązanymi dopiero w wyniku uchwalenia i implementacji dyrektywy V AMLD, zatem w okresie przygotowywania tego dokumentu Generalny Inspektor Informacji Finansowej (GIIF) mógł nie mieć pełnej informacji o tym rynku i o danych, którymi dysponowałby, gdyby przedsiębiorcy ci posiadali status instytucji obowiązanej. Niemniej nie zwalniało to Ministerstwa Finansów z bardziej rzetelnego przygotowania Krajowej oceny.

W świetle obecnych regulacji istnieje konieczność weryfikowania przez GIIF Krajowej oceny, a co dwa lata opracowanie nowej (art. 25 ustawy o przeciwdziałaniu praniu pieniędzy oraz finansowaniu terroryzmu). Tym samym, być może, objęcie podmiotów z obszaru rynku sztuki nowymi obowiązkami jako instytucji obowiązanych urealni, przynajmniej od strony danych, tę część Krajowej oceny, która jest poświęcona rynkowi sztuki.

Implementacja V AMLD do polskiego ustawodawstwa w zakresie obrotu dziełami sztuki bynajmniej nie miała charakteru „translatoryjnego”, czyli przepisania rozwiązań z V AMLD do ustawy o przeciwdziałaniu praniu pieniędzy oraz finansowaniu terroryzmu. W toku procesu legislacyjnego, a właściwie już na etapie samego złożenia projektu, dokonano pewnych korekt w zakresie strony podmiotowej i przedmiotowej. W myśl art. 2 ustawy z dnia 30 marca 2021 r. o zmianie ustawy o przeciwdziałaniu praniu pieniędzy oraz finansowaniu terroryzmu oraz niektórych innych ustaw instytucjami obowiązanymi są:

24a) przedsiębiorcy w rozumieniu ustawy z dnia 6 marca 2018 r. - Prawo przedsiębiorców prowadzący działalność polegającą na:

a) obrocie lub pośrednictwie w obrocie dziełami sztuki, przedmiotami kolekcjonerskimi oraz antykami w rozumieniu art. 120 ust. 1 pkt $1-3$ ustawy z dnia 11 marca 2004 r. o podatku od towarów i usług (Dz. U. z 2021 r. poz. 685, 694 i 802), w tym gdy działalność taka jest prowadzona:

- w galeriach sztuki lub domach aukcyjnych lub

- z wykorzystaniem wolnego portu rozumianego jako strefa lub pomieszczenie, w których towary są traktowane jako nieznajdujące się na obszarze celnym państw członkowskich lub państw trzecich, w tym z wykorzystaniem wolnego obszaru celnego,

b) przechowywaniu dzieł sztuki, przedmiotów kolekcjonerskich oraz antyków w rozumieniu art. 120 ust. 1 pkt 1-3 ustawy z dnia 11 marca 2004 r. o podatku od to- 


\section{ARTYKUŁY}

Wojciech Szafrański

warów i usług, gdy działalność taka jest prowadzona z wykorzystaniem wolnego portu, o którym mowa w lit. a tiret drugie

- w zakresie transakcji o wartości równej lub przekraczającej równowartość 10000 euro, bez względu na to, czy transakcja jest przeprowadzana jako pojedyncza operacja, czy kilka operacji, które wydają się ze sobą powiązane.

V AMLD posługuje się pojęciem „osoba”, natomiast polska ustawa pojęciem „przedsiębiorca”. Można to uznać za zabieg właściwy ze strony polskiego ustawodawcy, zważywszy na wyjątkową definicję przedsiębiorcy (i jej powiązanie z działalnością gospodarczą rozumianą z perspektywy określonego przychodu) w ustawie Prawo przedsiębiorców. Tym samym z perspektywy obrotu dziełami sztuki takimi instytucjami obowiązanymi są nie tylko galerie czy domy aukcyjne lub jeszcze inne podmioty - osoby prawne, ale także osoby fizyczne lub jednostki organizacyjne niebędące osobą prawną, której odrębna ustawa przyznaje zdolność prawną, wykonujące działalność gospodarczą. Nie stanowi natomiast działalności gospodarczej działalność wykonywana przez osobę fizyczną, której przychód należny z tej działalności nie przekracza w żadnym miesiącu 50\% kwoty minimalnego wynagrodzenia, o którym mowa w ustawie z dnia 10 października 2002 r. o minimalnym wynagrodzeniu za pracę ${ }^{26}$, i która w okresie ostatnich 60 miesięcy nie wykonywała działalności gospodarczej. Oznacza to, że istotna nie jest „forma organizacyjna”, lecz poziom przychodu i działalność w obrocie lub pośrednictwie w obrocie dziełami sztuki, przedmiotami kolekcjonerskimi i antykami. Przykładowo tzw. działacze na rynku (żyjący z handlu dziełami sztuki, choć nie jako klasyczni galerzyści, lecz dostarczający dzieła sztuki osobom prywatnym, galeriom, domom aukcyjnym) też są przedsiębiorcami w rozumieniu ustawy po przekroczeniu określonego przychodu, a tym samym są podmiotami obowiązanymi. Należy pamiętać, że podmiot staje się podmiotem obowiązanym, gdy wartość transakcji lub wielu powiązanych transakcji wyniesie 10 tys. euro lub więcej - nie wszyscy więc handlarze dziełami sztuki czy wskazani wyżej działacze staną się podmiotami obowiązanymi. Niewielka wiedza organów państwa o rynku sztuki każe wątpić w to, żeby GIIF w ogóle był w stanie objąć swoimi działaniami takie podmioty jak owi działacze ${ }^{27}$.

Od strony przedmiotowej także widać zróżnicowanie między V AMLD a znowelizowaną ustawą o przeciwdziałaniu praniu pieniędzy oraz finansowaniu terroryzmu. W V AMLD wyraźnie wskazane są „dzieła sztuki”, natomiast w polskiej ustawie jest odniesienie do art. 120 ust. 1-3 ustawy o VAT. Polski ustawodawca celowo poszerzył kategorię poprzez odwołanie, gdyż w ustawie

26 Ustawa z dnia 10 października 2002 r. o minimalnym wynagrodzeniu za pracę, Dz. U. z 2018 r., poz. 2177 oraz z 2019 r., poz. 1564.

27 Zagadnienia dotyczące freeportów, czyli stref wolnocłowych, zostały pominięte w niniejszym artykule z racji ograniczonej objętości oraz tego, że klasyczne freeporty nie występują w Polsce. Niemniej ustawodawca polski starał się objąć w tym zakresie regulacją przedsiębiorców, którzy właśnie na terenie RP oferują usługi związane z obrotem dziełami sztuki znajdującymi się w wolnych portach także w innych krajach, np. Chinach, Singapurze, Szwajcarii czy USA. 
o VAT znajdują się definicje zarówno dzieła sztuki, jak i przedmiotów kolekcjonerskich oraz antyków:

1) przez dzieła sztuki rozumie się:

a) obrazy, kolaże i podobne płyty dekoracyjne, rysunki i pastele, wykonane w całości przez artystę, z wyłączeniem planów i rysunków do celów architektonicznych, inżynieryjnych, przemysłowych, komercyjnych, topograficznych lub podobnych, ręcznie zdobionych produktów rzemiosła artystycznego, tkanin malowanych dla scenografii teatralnej, do wystroju pracowni artystycznych lub im podobnych zastosowań (CN 9701),

b) oryginalne sztychy, druki i litografie, sporządzone w ograniczonej liczbie egzemplarzy, czarno-białe lub kolorowe, złożone z jednego lub kilku arkuszy, w całości wykonane przez artystę, niezależnie od zastosowanego przez niego procesu lub materiału, z wyłączeniem wszelkich procesów mechanicznych lub fotomechanicznych (CN 97020000$)$

c) oryginalne rzeźby oraz posągi z dowolnego materiału, pod warunkiem że zostały one wykonane w całości przez artystę; odlewy rzeźby, których liczba jest ograniczona do 8 egzemplarzy, a wykonanie było nadzorowane przez artystę lub jego spadkobierców (CN 97030000$)$,

d) gobeliny (CN 580500 00) oraz tkaniny ścienne (CN 6304) wykonane ręcznie na podstawie oryginalnych wzorów dostarczonych przez artystę, pod warunkiem że ich liczba jest ograniczona do 8 egzemplarzy,

e) fotografie wykonane przez artystę, opublikowane przez niego lub pod jego nadzorem, podpisane i ponumerowane, ograniczone do 30 egzemplarzy we wszystkich rozmiarach oraz oprawach;

2) przez przedmioty kolekcjonerskie rozumie się:

a) znaczki pocztowe lub skarbowe, stemple pocztowe, koperty pierwszego obiegu, ostemplowane materiały piśmienne i im podobne, ofrankowane, a jeżeli nieofrankowane, to uznane za nieważne i nieprzeznaczone do użytku jako ważne środki płatnicze (CN 97040000$)$,

b) kolekcje oraz przedmioty kolekcjonerskie o wartości zoologicznej, botanicznej, mineralogicznej, anatomicznej, historycznej, archeologicznej, paleontologicznej, etnograficznej lub numizmatycznej (CN 970500 00), a także przedmioty kolekcjonerskie, o których mowa w art. 43 ust. 1 pkt 7;

3) przez antyki rozumie się przedmioty, inne niż wymienione w pkt 1 i 2, których wiek przekracza 100 lat (CN 97060000$)$.

Zdecydowano się więc w ustawie na odwołanie precyzyjne, by jasno określić, który przedsiębiorca jest obowiązany, a który nie z perspektywy przedmiotu obrotu. W praktyce jednak, podobnie jak w przypadku sporów klasyfikacyjnych przy okazji celów taryfowo-celnych, spory te będą bardzo istotne. Kluczowe może bowiem okazać się to, z jakiego materiału jest wykonane dzieło sztuki, by można je było zaliczyć do odpowiedniej kategorii, a w przypadku, gdy w wyniku określenia materiału wykonania dany obiekt nie będzie zaliczał się do kategorii dzieła sztuki ani nie będzie starszy niż 100 lat, czyli nie będzie zaliczał się do kategorii antyku, wtedy handlujący takimi obiektami przedsiębiorca nie będzie instytucją obowią- 


\section{ARTYKUŁY}

Wojciech Szafrański

zaną w świetle ustawy o przeciwdziałaniu praniu pieniędzy oraz finansowaniu terroryzmu. Sprawa jest jeszcze bardziej skomplikowana w przypadku rzeźby, i to nie tyle z racji materiału wykonania, ile kwestii liczby edycji dzieła , a więc relacji: oryginał - liczba. Ustawa o VAT wskazuje, że do dzieł sztuki zalicza się rzeźby wykonane $z$ dowolnego materiału „pod warunkiem że zostały one wykonane w całości przez artystę; odlewy rzeźby" (art. 120), których liczba jest ograniczona do 8 egzemplarzy, a wykonanie było nadzorowane przez artystę lub jego spadkobierców. W "myśleniu” taryfowo-celnym istotne zwielokrotnienie dzieła powoduje, że takie rzeźby pozostają poza kategoriami taryfowymi dzieła sztuki i mają charakter bardziej komercyjny niż artystyczny. Z perspektywy celnej UE czy regulacji dotyczących VAT wydaje się, że porządkuje to stosowanie konkretnych regulacji prawnych do konkretnych stanów faktycznych. W momencie jednak, gdy podległość regulacjom o przeciwdziałaniu praniu pieniędzy oraz finansowaniu terroryzmu z perspektywy rynku sztuki jest jak $w$ tym przypadku uzależnione od liczby egzemplarzy - stosunkowo niewielkiej (choć do niedawna typowej) w odniesieniu do rzeźb, wtedy od razu można sobie wyobrazić przypadek galerii, która właśnie chce uniknąć podporządkowania się nowym przepisom, a działa w sferze prania pieniędzy. Nie trzeba sobie nawet tego wyobrażać, bo rzeźbami, często w liczbie przekraczającej 8 obiektów, handlowały galerie New Form i Timeless. Na polskim rynku sztuki z kolei bardzo popularne prace Igora Mitoraja są odbijane w setkach, a nawet tysiącach edycji dzieł, osiągających wartość kilkudziesięciu tysięcy złotych (czyli przekraczających owe 10 tys. euro wskazanych w ustawie o przeciwdziałaniu praniu pieniędzy i finansowaniu terroryzmu). Część funkcjonujących na rynku sztuki podmiotów handluje obiektami, które w powszechnym rozumieniu są dziełami sztuki, ale jako instalacje nie zawsze byłyby zaliczane na podstawie art. 120 ust. 1 ustawy o VAT do dzieł sztuki, a tym bardziej do antyków (z racji wieku). Osobną kwestią są galerie zajmujące się fotografią - tu też liczba egzemplarzy w świetle art. 120 ustawy o VAT jest istotna (30 egzemplarzy), podczas gdy w rzeczywistości liczba egzemplarzy (także autorskich) danej fotografii jest bardzo różna. Ważne jest to, że przepisy ustawy mają zastosowanie tylko w przypadku, gdy wartość transakcji lub wielu powiązanych ze sobą transakcji wynosić będzie co najmniej 10 tys. euro. Co warte podkreślenia, treść uzasadnienia do ustawy implementującej dyrektywę V AMLD ${ }^{28}$ W ogóle nie przewiduje ryzyka związanego z zawężającym charakterem definicji zawartych w art. 120 ustawy o VAT.

Gdybyśmy kategorie zawarte w ustawie o VAT, a przeniesione do ustawy o przeciwdziałaniu praniu pieniędzy oraz finansowaniu terroryzmu, przyrównali do kategorii, którymi posługuje się ustawa o ochronie zabytków (także w części dotyczącej ksiąg ewidencyjnych), to pojęcie "dobro kultury" zawiera wszystkie te terminy, jest definicyjnie najszersze treściowo. Natomiast już między pojęciem dzieła

28 Druk sejmowy nr 909, Sejm IX kadencji, https://www.sejm.gov.pl/Sejm9.nsf/druk.xsp?nr=909 [dostęp 20.06.2021 r.] 
sztuki z ustawy o VAT a pojęciem zabytku z ustawy o ochronie zabytków zachodzi proces krzyżowania. Nieostrość definicji zabytku, zdaniem pośredników na rynku sztuki, powoduje, że w przypadku wielu obiektów uważają oni, że nie są objęci obowiązkiem wynikającym z prowadzenia ksiąg ewidencyjnych.

Podobnie będzie w przypadku niektórych podmiotów na rynku w odniesieniu do kategorii ustawowych - podmiotu obowiązanego. Tu też będą się pojawiać próby uniknięcia podporządkowania regulacjom prawnym i rozmaite interpretacje. Jednocześnie należy pamiętać, że w zakresie podmiotu obowiązanego istotną granicą jest 10 tys. euro, a w przypadku ksiąg ewidencyjnych zaledwie 10 tys. zł. Kluczowa jest zatem praktyka organów państwa, przede wszystkim GIIF, to, aby nowe regulacje nie zostały tylko na papierze ${ }^{29}$.

Zarówno dla rynku aukcyjnego czy - szerzej - wtórnego, jaki rynku pierwotnego (galeryjnego) zmiany w zakresie AML będą bardzo ważne. Galerie sztuki współczesnej (prowadzące swoich artystów) staną jednak przed wyzwaniem o wiele większym niż podmioty, które były już objęte rodzajem obowiązku informacyjnego, czyli obowiązkiem prowadzenia ksiąg ewidencyjnych. Dla małych podmiotów z pewnością uciążliwość na pierwszym etapie wdrażania nowych przepisów będzie większa, ale za to potencjalnie mniejsza (miarkowana) w niektórych sprawach będzie odpowiedzialność finansowa.

Jednocześnie mogą wystąpić problemy z „kwalifikacją przedmiotową”, a tym samym obowiązkami podmiotu.

Podstawowe zadania podmiotów obowiązanych można zebrać w następujące grupy:

1. Imienne wyznaczenie osób odpowiedzialnych za wdrożenie obowiązków, ich wykonywanie oraz zapewnienie zgodności działalności instytucji obowiązanej z regulacjami wewnętrznymi i zewnętrznymi.

2. Wdrożenie procedury przeciwdziałania praniu pieniędzy i finansowaniu terroryzmu oraz procedury odbierania zgłoszeń od sygnalistów i ich ochrony.

3. Wykonywanie analiz ryzyka i stosowanie środków bezpieczeństwa finansowego „różnego poziomu” - tu szczególnie istotne są działania podmiotu obowiązanego w zakresie nie tylko identyfikacji klienta, ale przede wszystkim trudnej w praktyce obrotu dziełami sztuki weryfikacji tożsamości klienta, osoby upoważnionej do działania w jego imieniu oraz beneficjenta rzeczywistego. Jest to w pewnym stopniu przerzucenie obowiązku z państwa na podmiot obowiązany, gdyż Centralny Rejestr Beneficjentów Rzeczywistych niczego podmiotowi obowiązanemu nie gwarantuje.

4. Archiwizacja wyników podjętych działań.

5. Przeprowadzenie szkoleń dla pracowników.

$29 \mathrm{Na}$ temat wyzwań stojących przed organami państwa w zakresie zwalczania prania pieniędzy zob. M. Brulińska, Aspekty prawne przeciwdziałania i zwalczania prania pieniędzy w Polsce. Wyzwanie dla polskich instytucji finansowych, „Studia luridica” 2018, nr 77, s. 7-22. 


\section{ARTYKUŁY}

Wojciech Szafrański

6. Obowiązek przechowywania dokumentacji przez 5 lat, licząc od dnia zakończenia stosunków gospodarczych z klientem lub od dnia przeprowadzenia transakcji okazjonalnej, która dotyczy archiwizacji podejmowanych działań, czyli przede wszystkim stosowanych środków bezpieczeństwa finansowego i dowodów potwierdzających przeprowadzone transakcje oraz ewidencji transakcji, obejmujący oryginalne dokumenty lub kopie dokumentów konieczne do identyfikacji transakcji. Właśnie ten obowiązek, w części dotyczący dowodów przeprowadzonych transakcji, jest w pewnym stopniu zbliżony do obowiązków wynikających z ksiąg ewidencyjnych w odniesieniu do zabytków o wartości powyżej 10 tys. zł. Może się on okazać kluczowy w walce z reżyserowaniem transakcji aukcyjnych i innymi patologiami w zakresie cen na rynku sztuki. Pozostaje jednak kluczowe pytanie: w jakim stopniu GIIF będzie korzystał z możliwości sprawdzania transakcji na potrzeby także innych postępowań ${ }^{30}$ ? W odniesieniu do podmiotów obowiązanych w obszarze rynku sztuki nie znajduje zastosowania możliwość przedłużenia o kolejne 5 lat przechowywania dokumentacji. Trudno powiedzieć, z jakiego powodu ustawodawca nie objął taką możliwością podmiotów wskazanych w art. 2 ust. 1 pkt 24a ustawy o przeciwdziałaniu praniu pieniędzy oraz finansowaniu terroryzmu. Na marginesie warto wskazać, że księgi ewidencyjne są cały czas przechowywane, a gdy podmiot zakończy działalność, przekazywane do właściwego archiwum.

7. Raportowanie do GIIF w przypadkach określonych w ustawie.

Warto jednocześnie wskazać, że dla pośredników na rynku sztuki istotnymi regulacjami pozostają te o wzmożonych środkach bezpieczeństwa finansowego, bo zgodnie z ustawą ustawy o przeciwdziałaniu praniu pieniędzy oraz finansowaniu terroryzmu, o wyższym ryzyku prania pieniędzy oraz finansowania terroryzmu może świadczyć w szczególności: powiązanie stosunków gospodarczych lub transakcji okazjonalnej z ropą naftową, bronią, metalami szlachetnymi, produktami tytoniowymi, artefaktami kulturowymi, kością słoniową, gatunkami chronionymi lub innymi przedmiotami o znaczeniu archeologicznym, historycznym, kulturowym i religijnym lub o szczególnej wartości naukowej (art. 43 ust 2 pkt 11 ustawy o przeciwdziałaniu praniu pieniędzy oraz finansowaniu terroryzmu - obowiązuje on w nowym brzmieniu od 31.10.2021 r.). Ustawodawca wprowadził bowiem kolejne pojęcia: „artefakty kulturowe” „przedmioty o znaczeniu archeologicznym, historycznym, kulturowym i religijnym lub o szczególnej wartości naukowej". Nie są one

30 Kwestia dotycząca zbierania dowodów i wykorzystywania informacji wymaga szczególnej ostrożności takich organów jak GIIF czy Krajowa Administracja Skarbowa. Dowodem tego może być wyrok Wojewódzkiego Sądu Administracyjnego w Gdańsku z dnia 23 czerwca 2021 r., sygn. akt I SA/Gd 886/20 LEX nr 3198542, dotyczący możliwości zbierania dowodów przez organ na podstawie art. 45 ustawy o Krajowej Administracji Skarbowej. Przedmiotem było postanowienie Dyrektora Izby Administracji Skarbowej o udostępnieniu i przekazaniu danych wszystkich osób fizycznych, które w latach 2018-2019 dokonały nabycia oraz zbycia dzieł sztuki o wartości powyżej 20 tys. złotych. Wojewódzki Sąd Administracyjny uchylił owo postanowienie jako wychodzące poza kompetencje wynikające z art. 45 ust. 1 ustawy o Krajowej Administracji Skarbowej. 
tożsame z zabytkami czy dobrami kultury, choć generalnie wszystkie te kategorie mieszczą się w kategorii dóbr kultury. Zastosowanie wzmożonych środków bezpieczeństwa finansowego powoduje konieczność wzięcia pod uwagę przez podmiot obowiązany większej liczby tzw. red flag.

Ustawa wskazuje wiele obowiązków informacyjnych względem GIIF:

- informowanie Generalnego Inspektora o transakcjach ponadprogowych,

- informowanie Generalnego Inspektora o podejrzeniu popełnienia przestępstwa prania pieniędzy lub finansowania terroryzmu,

- przekazywanie Generalnemu Inspektorowi żądanych przez niego informacji w określonym przez Generalnego Inspektora terminie,

- informowanie Generalnego Inspektora o przypadku powzięcia uzasadnionego podejrzenia, że określona transakcja lub określone wartości majątkowe mogą mieć związek z praniem pieniędzy lub finansowaniem terroryzmu (tzw. transakcje podejrzane),

- informowanie Generalnego Inspektora o przeprowadzeniu podejrzanej transakcji, AML

- przekazywanie Generalnemu Inspektorowi przygotowanej przez instytucję obowiązaną swojej oceny ryzyka oraz innych informacji, które mogą mieć wpływ na krajową ocenę ryzyka,

- informowanie właściwego prokuratora o uzasadnionym podejrzeniu, że wartości majątkowe będące przedmiotem transakcji lub zgromadzone na rachunku pochodzą z przestępstwa innego niż przestępstwo prania pieniędzy lub finansowania terroryzmu lub mają związek z takim przestępstwem;

- informowanie właściwego prokuratora o dokonaniu przez instytucję obowiązaną transakcji (przy podejrzeniu prania brudnych pieniędzy).

Szczególnie istotne z perspektywy rynku sztuki i obowiązków z tytułu AML będą sytuacje, w których przedsiębiorca, czyli np. galeria czy dom aukcyjny, jako instytucja obowiązana nie może zastosować jednego ze środków bezpieczeństwa finansowego (identyfikacji klienta czy weryfikacji jego tożsamości). W takim wypadku nie powinien m.in. nawiązać stosunków gospodarczych czy przeprowadzić transakcji okazjonalnej. Ustawa wskazuje, że wówczas to instytucja obowiązana ocenia, czy niemożność zastosowania środków bezpieczeństwa finansowego stanowi podstawę do przekazania Generalnemu Inspektorowi zawiadomienia. Na polskim rynku sztuki niestety jest mało prawdopodobne, że przepis ten znajdzie zastosowanie. Doświadczenia płynące bowiem z innego obszaru, tj. niezawiadamianie organów ścigania o falsyfikatach przez pośredników, stawiają pod znakiem zapytania także podejmowanie wyżej wskazanych działań w ramach AML.

Na marginesie warto jeszcze poruszyć kwestię możliwości, które daje art. 73 ustawy o przeciwdziałaniu praniu pieniędzy oraz finansowaniu terroryzmu. Zgodnie z nim, informacje wskazane $w$ art. 72 niniejszej ustawy ${ }^{31}$ mogą być przekazy-

31 Dotyczy przede wszystkim raportowania do GIIF o transakcjach ponadprogowych. 


\section{ARTYKUŁY}

Wojciech Szafrański

wane, w tym przy wykorzystaniu systemu teleinformatycznego, do Generalnego Inspektora za pośrednictwem np. izb gospodarczych zrzeszających instytucje obowiązane. Pośrednicy na polskim rynku sztuki nie wypracowali dotychczas formuły współpracy w postaci izby gospodarczej. Na polskim rynku sztuki jest już wystarczająca liczba podmiotów, by taką izbę założyć (szczególnie że obejmowałaby ona podmioty z rynku pierwotnego i wtórnego). Funkcjonowanie w obrębie izby gospodarczej daje większe możliwości wpływania np. na proces legislacyjny w ramach konsultacji publicznych. Dotychczas niezmieniona forma stowarzyszeniowa części podmiotów na rynku w postaci Stowarzyszenia Antykwariuszy i Marszandów Polskich w moim przekonaniu się wyczerpała, jeśli wziąć pod uwagę to, że do organizacji tej nie należą często najsilniejsze pod względem ekonomicznym podmioty na polskim rynku.

Odpowiedzialność za niedopełnienie obowiązków przez podmiot obowiązany skutkuje możliwością nałożenia kar administracyjnych ${ }^{32}$. Są one dość zróżnicowane, np. od nakazu zaprzestania podejmowania przez instytucję obowiązaną określonych czynności aż do nałożenia kary pieniężnej. Karę pieniężną można nałożyć do wysokości dwukrotności kwoty korzyści osiągniętej lub straty unikniętej przez instytucję obowiązaną w wyniku naruszenia albo - w przypadku, gdy nie jest możliwe ustalenie kwoty tej korzyści lub straty - do wysokości równowartości kwoty $1 \mathrm{mln}$ euro (na zasadach miarkowania). Podobnie jak we wskazanym wyżej przypadku, tj. niemożności przedłużenia przez GIIF pięcioletniego okresu przechowywania dokumentacji przez podmiot obowiązany na kolejne 5 lat, także w tym wypadku ustawodawca nie zastosował względem podmiotów obowiązanych w obszarze obrotu dziełami sztuki zaostrzonej odpowiedzialności finansowej w postaci możliwości nałożenia kary nawet do $5 \mathrm{mln}$ euro albo do wysokości $10 \%$ obrotu wykazanego w ostatnim zatwierdzonym sprawozdaniu finansowym za rok obrotowy. Ustawa o przeciwdziałaniu praniu pieniędzy i finansowaniu terroryzmu w ramach możliwych kar administracyjnych wprowadza możliwość cofnięcia koncesji lub zezwolenia albo wykreślenie z rejestru działalności regulowanej (art. 150 ust. 1 pkt 3). Obecnie działalność w zakresie szeroko pojętego obrotu dobrami kultury nie jest koncesjonowana czy objęta jakimś rodzajem zezwolenia. Niemniej można dostrzec tendencję do obejmowania tego typu działalności jakąś formą zgłoszenia, tak by organy państwa miały w ogóle wiedzę o liczbie takich podmiotów i mogły stosować względem nich szczególne wymogi - przeznaczone dla tych podmiotów reguły należytej starannościj3. W wielu systemach prawnych rażące naruszenie

\footnotetext{
32 Zob. T. Mierzwiński, w: Przeciwdziałanie praniu pieniędzy oraz finansowaniu terroryzmu. Komentarz, W. Kapica (red.), Wolters Kluwer Polska, Warszawa 2020, art. 150.

33 Zob. także jedną z inicjatyw TIAMSA w zakresie RAM (The Responsible Art Market Initiative) w postaci: Art Transaction Due Diligence Toolkit - Explanatory Notes, http://responsibleartmarket.org/guidelines/ art-transaction-due-diligence-toolkit/ [dostęp: 20.06.2021] oraz Guidelines on combatting Money Laundering and Terrorist Financing, http://responsibleartmarket.org/guidelines/guidelines-on-combatting-money-laundering-and-terrorist-financing/ [dostęp: 20.06.2021].
} 
due diligence skutkuje niemożnością dalszego wykony wania takiego rodzaju działalności. Tym samym wskazany wyżej art. 150 ust. 1 pkt 3 może mieć istotne znaczenie dla podmiotów obowiązanych $w$ ramach rynku sztuki wraz z wprowadzeniem do systemu prawnego konstrukcji należytej staranności, powiązanej z formą zgłoszenia takiej działalności organowi państwa.

\section{„Trójkąt podmiotów" - możliwa przyszłość}

Implementacja dyrektywy $\mathrm{V}$ AML, poświęconej m.in. rynkowi sztuki, przypomina trochę sytuację znalezienia się między Scyllą i Charybdą - bo nie ma wyjścia i dyrektywa musi zostać wprowadzona, jest wynikiem tego, co się dzieje na dużych, dojrzałych rynkach zachodnioeuropejskich, a nie na naszym rodzimym rynku, lecz może prowadzić do daleko idących zmian na linii państwo - rynek sztuki, stanowiąc katalizator do dalszych modyfikacji prawnych i faktycznych na tym rynku. Kto zostanie Odyseuszem, będzie się można dopiero przekonać w przyszłości.

Przedstawiciele pośredników polskiego rynku sztuki, którzy w większości przypadków stali się po wejściu w życie ustawy podmiotami obowiązanymi, nie wzięli aktywnego udziału w dyskusji w toku procesu legislacyjnego - w przeciwieństwie do innych grup "zawodowych" objętych nowymi obowiązkami wynikającymi z V AMLD. W związku z tym pojawia się pytanie nie tyle o siłę czy bezsilność tego środowiska, ile raczej o poziom przekonania o braku realnego wpływu na kształt ustawy albo wręcz małe zainteresowanie i uznawanie przez wielu pośredników na rynku sztuki, że przepisy istnieją tylko na papierze, a ich działalność i tak będzie szła niezmienionym torem. I tu znów istotna okaże się aktywność organów państwa w obszarze AML. Jednocześnie dla podmiotów obowiązanych na rynku sztuki AML może okazać się dużym wyzwaniem, bo choć funkcjonują już przedsiębiorstwa zajmujące się profesjonalnie usługami w zakresie AML $i$ istnieją związane z tym programy komputerowe (np. do raportowania), to jednak na pewno powstanie wiele problemów w praktyce stosowania tych przepisów. We wcześniejszym okresie GIIF miał obowiązek ustawowy udzielania indywidualnych interpretacji przepisów z zakresu ustawy o przeciwdziałaniu praniu pieniędzy oraz finansowaniu terroryzmu. Obecnie może on udostępniać wiedzę i informacje z zakresu przepisów o przeciwdziałaniu praniu pieniędzy oraz finansowaniu terroryzmu na stronach Biuletynu Informacji Publicznej, a udzielanie indywidualnych interpretacji już nie obowiązuje. Ważne jest zatem to, aby podmioty obowiązane funkcjonujące na rynku sztuki wypracowały pewien wspólny - jednolity model działania.

Kluczowa dla rynku sztuki w zakresie regulacji o przeciwdziałaniu praniu pieniędzy okaże się praktyka GIIF. Istnieją trzy możliwe drogi w odniesieniu do układu organy państwa - rynek sztuki:

1. Brak działań zarówno organów, jak i nowych podmiotów obowiązanych. Wydaje się to mało możliwe, gdyż z jednej strony GIIF jest rozliczany z działań w tym zakresie (kontrole NIK, opracowanie Krajowej oceny itd.), z drugiej zaś - potencjal- 


\section{ARTYKUŁY}

Wojciech Szafrański

ne kary wynikające z ustawy, które dotknąć mogą podmioty obowiązane, realnie wpłyną na konieczność podjęcia choćby podstawowych działań przez podmioty obowiązane. Jednocześnie istotne jest to, że GIIF sprawuje kontrolę wykonywania przez instytucje obowiązane obowiązków w zakresie przeciwdziałania praniu pieniędzy oraz finansowaniu terroryzmu, a jednocześnie przygotowuje tzw. roczne plany kontroli i prowadzi kontrole doraźne. Tym samym w odniesieniu do nowo obowiązanych podmiotów działających na rynku sztuki też będzie zmuszony prowadzić takie kontrole w przypadku powzięcia wiadomości o wystąpienia poważnych naruszeń z tytułu AML.

2. Natychmiastowa reakcja organów państwa i nowych podmiotów obowiązanych. Także ta droga wydaje się mało realna. $Z$ jednej strony to przedsiębiorcy muszą umieć dostosować się do wymogów ustawowych i przy tak daleko idących zmianach potrzebują więcej czasu, niż wynika to z klasycznego vacatio legis przy tej nowelizacji. $Z$ drugiej strony jednak także organy państwa, przede wszystkim GIIF, muszą podjąć działania choćby w zakresie samych instytucji obowiązanych i podstawowych wspólnych wymogów. Obecnie organy państwa wykazują małą znajomość rynku sztuki i specyfiki podmiotów oraz mechanizmów na nim występujących. Tym samym także organy państwa muszą przygotować się do potencjalnych działań względem rynku sztuki.

3. Opóźniona reakcja podmiotów obowiązanych, wynikająca z konieczności poszukiwań nieraz wspólnych działań, wymiany informacji, ale przede wszystkim ustalenia wspólnej praktyki przez pośredników na rynku sztuki. Droga ta wydaje się najbardziej prawdopodobna, a właściwie już się realizuje. Organy państwa powinny mieć czas na zidentyfikowanie potencjalnych problemów, na szkolenia, czyli dobre przygotowanie. Istotna jest także przyszła opóźniona reakcja innych uczestników rynku (rodzaj opóźnionego „szoku”), która nastąpi wtedy, gdy rzeczywiście regulacje będą egzekwowane i przestrzegane, bo dopiero wówczas zetkną się z nimi potencjalni nabywcy i zbywcy - szczególnie nowi, nieznani pośrednikom na rynku, a więc tacy, którzy winni przejść procedurę tzw. KYC (Know Your Client) typową w przypadku AML.

Wskazywane wyżej wprowadzenie przedsiębiorców zajmujących się obrotem dobrami/dziełami sztuki do trójkąta, w którym oddziaływać poprzez przyszłe regulacje będzie na nich z jednej strony projektodawca w postaci MF, a z drugiej projektodawca w postaci MKDNiS, którzy mają odmienne cele, ale przede wszystkim różne spojrzenia na rynek sztuki, przy jednoczesnym unikaniu przez jakikolwiek organ państwa zajmowania się kompleksowo rynkiem sztuki, powodować będzie komplikacje dla pośredników i uczestników tego rynku. Regulacje wynikające z implementacji V AMLD do polskiego porządku prawnego nie wypchną z systemu regulacji dotyczących np. ksiąg ewidencyjnych. Nie jest też możliwa sytuacja odwrotna - bo przy pozornej bliskości regulacje te należą do różnych kategorii. Przyszłość raczej rysuje się jako podążanie w kierunku wyodrębnionej należytej staranności w obrocie dobrami kultury - jednej ogólnej, podstawowej dla wszystkich, 
drugiej - dla przedsiębiorców, których przedmiotem działalności jest obrót dobrami kultury ${ }^{34}$. Spowoduje to $z$ jednej strony eliminację ksiąg ewidencyjnych w formie dotychczas znanej, z drugiej zaś kompatybilność regulacji związanych z księgami ewidencyjnymi z regulacjami z obszaru obrotu gospodarczego jako takiego albo pozostawienie swoistego dualizmu, jaki ma miejsce obecnie.

Rozwiązania w tym zakresie nie są bynajmniej proste do zastosowania, gdyż z perspektywy Ministerstwa Finansów ustawa o podatku od towarów i usług implementuje postanowienia dyrektywy Rady 2006/112/WE z dnia 28 listopada 2006 r. w sprawie wspólnego systemu podatku od wartości dodanej ${ }^{35} \mathrm{i}$ musi przede wszystkim realizować cele podatkowe, zapewnić spójność stosowania europejskiego systemu VAT we wszystkich państwach członkowskich UE, a dopiero w dalszej kolejności może kształtować inne instytucje prawne. Również umiejscowienie definicji: „dzieło sztuki”, „przedmiot kolekcjonerski” i „antyk” w art. 120 ustawy o VAT (czyli w rozdziale wprowadzającym preferencyjny system opodatkowania, tzw. szczególną procedurę VAT marża) wskazuje, że ma ona zawężający charakter, określający zakres przedmiotowy możliwości skorzystania z tej procedury szczególnej. Prawo podatkowe jest autonomiczną gałęzią prawa i nierzadko stosuje własną terminologię $\mathrm{w}$ celu determinowania kształtu obowiązku podatkowego i ewentualnej wysokości zobowiązania podatkowego. Dlatego też definicje mogą mieć (i mają) zawężający charakter (np. ograniczenie liczby rzeźb do ośmiu, wieku antyku do ponad 100 lat), aby ograniczyć potencjalny krąg osób uprawnionych do skorzystania z preferencyjnego reżimu opodatkowania. Artykuł 120 ustawy o VAT stanowi implementację art. 311 dyrektywy 2006/112/WE, a zatem według Ministerstwa Finansów ustawa o VAT niekoniecznie musi zapewnić spójność terminologiczną pojęć należących do systemu ochrony dziedzictwa.

\section{Bibliografia}

Aneks nr 2 „Scenariusze ryzyka prania pieniędzy”, https://www.gov.pl/attachment/ 6d2509ff-5ff3-4928-b81d-3f096253721d [dostęp: 20.06.2021].

Art Transaction Due Diligence Toolkit - Explanatory Notes, http://responsibleartmarket.org/ guidelines/art-transaction-due-diligence-toolkit/ [dostęp: 20.06.2021].

Banasiak J., Proteuszowe czasy. Rozpad państwowego systemu sztuki 1982-1993, Muzeum Sztuki Nowoczesnej i Akademia Sztuk Pięknych w Warszawie, Warszawa 2020.

Brulińska M., Aspekty prawne przeciwdziałania i zwalczania prania pieniędzy w Polsce. Wyzwanie dla polskich instytucji finansowych, „Studia luridica” 2018, nr 77.

Druk sejmowy nr 909, Sejm IX kadencji, https://www.sejm.gov.pl/Sejm9.nsf/druk.xsp? $\mathrm{nr}=909$ [dostęp 20.06.2021].

Dyrektywa Parlamentu Europejskiego i Rady (UE) 2018/843 z dnia 30 maja 2018 r. zmieniająca dyrektywę (UE) 2015/849 w sprawie zapobiegania wykorzystywaniu systemu

\footnotetext{
34 Kwestie dotyczące specjalnego kodu PKD, prowadzenia listy takich przedsiębiorców itd. są wtórne względem całego zarysowanego sytemu i dość łatwe do wprowadzenia.

35 Dyrektywa Rady 2006/112/WE z dnia 28 listopada 2006 r. w sprawie wspólnego systemu podatku od wartości dodanej, Dz. U. UE L 347 s. 1 z 28.11.2006 r. ze zm.
} 


\section{ARTYKUŁY}

Wojciech Szafrański

finansowego do prania pieniędzy lub finansowania terroryzmu oraz zmieniająca dyrektywy 2009/138/WE i 2013/36/UE, Dz. Urz. UE L 156 z 19.06.2018 r.

Dyrektywa Rady 2006/112/WE z dnia 28 listopada 2006 r. w sprawie wspólnego systemu podatku od wartości dodanej, Dz. U. UE L 347 s. 1 z 28.11.2006 r. ze zm.

Guidelines on combatting Money Laundering and Terrorist Financing, http://responsibleartmarket.org/guidelines/guidelines-on-combatting-money-laundering-and-terrorist-financing/ [dostęp: 20.06.2021].

Krajowa ocena ryzyka prania pieniędzy oraz finansowania terroryzmu, Ministerstwo Finansów, Warszawa 2019, https://www.gov.pl/attachment/717264b0-2867-4e41-98da-2e64cf158ac8 [dostęp: 20.06.2021].

Mierzwiński T., w: Przeciwdziałanie praniu pieniędzy oraz finansowaniu terroryzmu. Komentarz, W. Kapica (red.), Wolters Kluwer Polska, Warszawa 2020.

Neville R., The art market is 'high risk' for money laundering, so ignore new regulations at your peril, „The Art Newspaper”, 26.03.2021, https://www.theartnewspaper.com/comment/art-dealer-vs-solicitor-money-laundering-law-alters-the-relationship [dostęp: 20.06.2021].

Paczuski W., Handel dziełami sztuki w Unii Europejskiej, Wolters Kluwer, Kraków 2005.

Pływaczewski W., Patologie w obrębie współczesnego rynku dzieł sztuki - perspektywa krajowa i międzynarodowa, w: T. Gardocka, J. Sobczak (red.), Prawna ochrona zabytków, Wydawnictwo Adam Marszałek, Toruń 2014.

Pływaczewski W., Pranie pieniędzy oraz inne nielegalne transakcje finansowe z perspektywy międzynarodowego rynku dzieł sztuki, w: E.W. Pływaczewski (red.), Proceder prania pieniędzy i jego implikacje, Wolters Kluwer Polska, Warszawa 2013.

Rozporządzenie Ministra Kultury i Dziedzictwa Narodowego z dnia 4 grudnia 2017 r. w sprawie ksiąg ewidencyjnych prowadzonych przez podmioty gospodarcze wyspecjalizowane z zakresie obrotu zabytkami na terytorium Rzeczypospolitej Polskiej, Dz. U. poz. 2249.

Rozporządzenie Rady (EWG) nr 2658/87 w sprawie nomenklatury taryfowej i statystycznej oraz w sprawie wspólnej taryfy celnej, Dz. U. WE L 256 z 7.09.1987.

Rozporządzenie Rady (WE) nr 254/200, Dz. U. WE L 28 z 3.02.2001.

Szafrański W., Mity i patologie obrotu dziełami sztuki, „Santander Art and Culture Law Review" 2015, nr 1(1).

Szafrański W., Ochrona dziedzictwa kulturalnego a rynek sztuki. Zagrożenia, korzyści, perspektywy, w: W. Pływaczewski, B. Gadecki (red.), Ochrona dziedzictwa kulturowego i naturalnego. Perspektywy prawna i kryminologiczna, C.H. Beck, Warszawa 2015.

Szafrański W., Rynek sztuki w Polsce z perspektywy administracji publicznej, w: M. Jankowska, P. Gwoździewicz-Matan, P. Stec (red.), Własność intelektualna a dziedzictwo kulturowe. Księga jubileuszowa dedykowana Profesorowi Wojciechowi Kowalskiemu, Ius Publicum, Warszawa 2020.

Ustawa z dnia 23 grudnia 1988 r. o działalności gospodarczej, Dz. U. Nr 41, poz. 324.

Ustawa z dnia 10 października 2002 r. o minimalnym wynagrodzeniu za pracę, Dz. U. z 2018 r., poz. 2177 oraz z 2019 r., poz. 1564.

Ustawa z dnia 23 lipca 2003 r. o ochronie zabytków i opiece nad zabytkami, Dz. U. Nr 162, poz. 1568 ze zm.

Ustawa z dnia 11 marca 2004 r. o podatku od towarów i usług, Dz. U. Nr 54, poz. 535.

Ustawa z dnia 25 maja 2017 r. o restytucji narodowych dóbr kultury, Dz. U. poz. 1086.

Ustawa z dnia 6 marca 2018 r. Prawo przedsiębiorców, Dz. U. poz. 646.

Ustawa z dnia 30 marca 2021 r. o zmianie ustawy o przeciwdziałaniu praniu pieniędzy oraz finansowaniu terroryzmu oraz niektórych innych ustaw, Dz. U. poz. 815. sygn. akt I SA/Gd 886/20 LEX nr 3198542. 